\title{
Angiotensin converting enzyme gene polymorphism is associated with severity of coronary artery disease in men with high total cholesterol levels
}

\author{
Joanna Borzyszkowska • \\ Anna Stanislawska-Sachadyn • Marcin Wirtwein • \\ Wojciech Sobiczewski • Dariusz Ciecwierz • \\ Radoslaw Targonski • Marcin Gruchala • \\ Andrzej Rynkiewicz • Janusz Limon
}

Received: 25 October 2011 /Revised: 1 January 2012 / Accepted: 3 January 2012 / Published online: 4 February 2012

(C) The Author(s) 2012. This article is published with open access at Springerlink.com

\begin{abstract}
This study examines whether renin-angiotensinaldosterone system gene polymorphisms: $A C E$ (encoding for angiotensin converting enzyme) c.2306-117_404 I/D, $A G T R 1$ (encoding for angiotensin II type-1 receptor) c. $1080 * 86 \mathrm{~A}>\mathrm{C}$ and $C Y P 11 B 2$ (encoding for aldosterone synthase) c. $-344 \mathrm{C}>\mathrm{T}$ are associated with the extension of coronary atherosclerosis in a group of 647 patients who underwent elective coronary angiography. The extension of CAD was evaluated using the Gensini score. The polymorphisms were determined by PCR and RFLP assays. The associations between genotypes and the extent of coronary atherosclerosis were tested by the Kruskal-Wallis test, followed by pairwise comparisons using Wilcoxon test. The population has been divided into groups defined by: sex, smoking habit, past myocardial infarction, BMI $(>, \leq 25)$, age $(>, \leq 55)$, diabetes mellitus, level of total cholesterol
\end{abstract}

J. Borzyszkowska $\cdot$ A. Stanislawska-Sachadyn $\cdot$ J. Limon $(\triangle)$

Department of Biology and Genetics,

Medical University of Gdansk,

Debinki 1,

80-211 Gdansk, Poland

e-mail: jlimon@gumed.edu.pl

M. Wirtwein · W. Sobiczewski • M. Gruchala • A. Rynkiewicz First Department of Cardiology, Medical University of Gdansk, Debinki 7,

80-211 Gdansk, Poland

D. Ciecwierz $\cdot$ R. Targonski

Department of Invasive Cardiology,

Medical University of Gdansk,

Debinki 7 ,

80-211 Gdansk, Poland
$(>, \leq 200 \mathrm{mg} / \mathrm{dl})$, LDL cholesterol $(>, \leq 130 \mathrm{mg} / \mathrm{dl})$, HDL cholesterol $(>, \leq 40 \mathrm{mg} / \mathrm{dl})$, triglycerides $(>, \leq$ $150 \mathrm{mg} / \mathrm{dl})$. Significant associations between the $A C E$ c.2306-117_404 I/D polymorphism and the Gensini score in men with high total cholesterol levels $\left(\mathrm{P}_{\text {Kruskal-Wallis }}=\right.$ $0.008 ; \mathrm{P}_{\text {adjusted }}=0.009$ ), high level of LDL cholesterol $\left(\mathrm{P}_{\text {Kruskal-Wallis }}=0.016 ; \mathrm{P}_{\text {adjusted }}=0.028\right)$ and low level of HDL cholesterol $\left(\mathrm{P}_{\text {Kruskal-Wallis }}=0.04 ; \mathrm{P}_{\text {adjusted }}=0.055\right)$ have been found. No association between the AGTR1 c. $1080 * 86 \mathrm{~A}>\mathrm{C}$ and $C Y P 11 B 2$ c. $-344 \mathrm{C}>\mathrm{T}$ and the Gensini score has been found. These results suggest that men who carry $A C E$ c.2306-117_404 DD genotype and have high total cholesterol, high LDL cholesterol and low HDL cholesterol levels may be predisposed to the development of more severe CAD.

Keywords $A C E \cdot A G T R 1 \cdot$ Atherosclerosis · CAD · CYP11B2 - Gensini score

\section{Introduction}

Coronary artery disease (CAD) is a major public health problem in many industrialized countries and remains the leading cause of death in most of them. The renin-angiotensinaldosterone system (RAAS) is a well-described hormone system that regulates blood pressure and salt/water homeostasis. RAAS dysfunction contributes to functional and structural perturbations that occur in atherosclerosis formation (Farmer and Torre-Amione 2001).

The studies investigating the relation between the RAAS gene polymorphisms and CAD progression are designed 
either to search for an association between the polymorphisms and the atherosclerosis severity represented by the chosen scale of arterial narrowing (e.g. Gensini, jeopardy, Leaman's, number of vessels narrowed at least in $50 \%$ or $75 \%$ ), which is the approach we applied, or to evaluate the $\mathrm{CAD}$ risk associated with the presence of specific genotype in case-control studies, the approach that prevails.

The most studied and clinically important polymorphism in the angiotensin converting enzyme gene $(A C E)$ is an insertion/deletion (I/D) of a $288 \mathrm{bp} A l u$ repeat sequence within the intron 16 (ACE c.2306-117_404, rs4340). ACE c.2306-117_404 I/D polymorphism has been suggested to be related to approximately $50 \%$ of the variability in the ACE levels in the bloodstream, with the highest values present among DD homozygotes (Rigat et al. 1990). Further, the $A C E$ c.2306-117_404 I/D polymorphism has been widely investigated as a CAD risk factor (Zintzaras et al. 2008; Agerholm-Larsen et al. 2000). An association between this polymorphism and the extent of coronary atherosclerosis has been reported for populations ranging from 152 to 1162 participants (Ye et al. 2003; Mendonca et al. 2004; Niemiec et al. 2008a; Hibi et al. 1997), although other studies did not report such an association (Jeunemaitre et al. 1997; Nakauchi et al. 1996; Qiu et al. 2007; Foy et al. 1997; van Geel et al. 2001)

The $1166 \mathrm{~A}>\mathrm{C}$ substitution within the $3^{\circ}$ untranslated region of the angiotensin II type-1 receptor gene (AGTR1 c. $1080 * 86 \mathrm{~A}>\mathrm{C}$, rs5186) occurs in a cis-regulatory region recognized by a specific microRNA-155 (miR-155) (Martin et al. 2007). For the $\mathrm{C}$ allele, the base-pairing complementarity of miR-155 and the AGTR1 transcript is interrupted, thus decreasing the ability of miR-155 to interact with the cis-regulatory site, which results in miR-155 being no longer an attenuator of translation, which further leads to a higher expression of AGTR1 (Martin et al. 2007). It has been demonstrated that AGTR1 expression is significantly increased in the $\mathrm{CC}$ homozygotes in comparison to AA and AC genotype carriers (Ceolotto et al. 2011). The AGTRI c. $1080 * 86 \mathrm{~A}>\mathrm{C}$ polymorphism has been investigated as a $\mathrm{CAD}$ risk factor (Xu et al. 2010). Further, the correlation between the AGTR1 c. $1080 * 86 \mathrm{~A}>\mathrm{C}$ polymorphism and the extension of CAD has been found by some (Nakauchi et al. 1996; Qiu et al. 2007) (study populations of 133 and 130 participants, respectively), but not by all investigators (Gardemann et al. 1998; van Geel et al. 2001; Jeunemaitre et al. 1997) (study populations ranging from 463 to 2244 participants).

The aldosterone synthase gene $(C Y P 11 B 2)$ polymorphism (CYP11B2 c.-344C>T, rs1799998) is located within the steroidogenic factor-1 (SF-1) binding site, thus SF-1 binding capability has been suggested to vary between the alleles, although this hypothesis has not been finally confirmed (White and Rainey 2005) and thus the potential biological functionality needs to be yet determined. To our knowledge, the association between the CYP11B2 c. $-344 \mathrm{C}>\mathrm{T}$ polymorphism and the extent of atherosclerosis in $\mathrm{CAD}$ has not been reported; however the CYP11B2 c. $-344 \mathrm{C}>\mathrm{T}$ polymorphism has been related to the severity of atherosclerotic plaque size in the carotid artery (Sharma and Katz 2010). Previously the relationship between the CYP11B2 c.-344C > T polymorphism and hypertension (Sookoian et al. 2007) has been extensively studied. Also, to date, either the $\mathrm{T}$ (Casiglia et al. 2005) or $\mathrm{C}$ allele (Tsukada et al. 2002) have been reported to be risk factors in cardiovascular events. However, a study finding no relation has also been published (Payne et al. 2004).

The aim of the present study was to examine whether three common RAAS genes polymorphisms: $A C E$ c.2306117_404 I/D, AGTR1 c. $1080 * 86 \mathrm{~A}>\mathrm{C}$ and $C Y P 11 B 2$ c. $-344 \mathrm{C}>\mathrm{T}$ are associated with the extension of coronary atherosclerosis, represented by the Gensini score, which is a reliable estimate of the severity of coronary artery stenosis (Gensini 1983), in a relatively large cohort of 647 PolishCaucasian patients undergoing elective coronary angiography.

\section{Materials and methods}

\section{Subjects}

The patients were admitted to the First Department of Cardiology, Medical University of Gdansk, Poland, between 2005 and 2007 for elective coronarography due to CAD. The patients were on pharmacological treatment prior to the coronarography. Further, only those patients who had undergone first-time coronary angiography for suspected CAD were included. The resultant study population consisted of 647 consecutive patients (368 males, 279 females).

Fasting blood samples were tested for levels of: total cholesterol, high-density lipoprotein (HDL) cholesterol and triglycerides (TG) with the use of standard enzymaticcolorimetric methods. The low-density lipoprotein (LDL) cholesterol level was calculated according to the Friedewald formula. Smoking habit (smoker, non-smoker, ex-smoker) was self-reported by study participants. All subjects were Polish Caucasians and gave their written informed consent to take part in this study. The study was approved by the Ethical Committee of the Medical University of Gdansk, Poland.

Estimation of the severity of coronary stenosis

The patients underwent coronary angiography in accordance with standard protocols. The severity of CAD was evaluated by Gensini scores determined by examining coronary angiograms. Gensini score is a point scale, which is based on the 
number of stenotic coronary artery segments including degree of its luminal narrowing and the localization of the stenosis (Gensini 1983). Thus the Gensini score is calculated as a sum of stenosis scores and functional significance scores calculated for each segment of the coronary artery tree. Stenosis score expresses the percentage of the reduction in the diameter of the coronary artery lumen (the score was given from 1 to 32 for complete occlusion). The functional significance score illustrates the regional importance of the lesion's position (the score was given from 0.5 to 5). Gensini score equals 0 if there is no stenotic change in any of the coronary arteries segment whereas the maximal value is achieved for theoretical total occlusion in the main segments of the coronary artery tree.

Genetic analyses

Genomic DNA was isolated from peripheral blood lymphocytes in accordance with a standard phenol-chloroform method.

A polymerase chain reaction (PCR) assay was performed to detect the $A C E$ c.2306-117_404 I/D polymorphism. The primer sequences were modified from Rigat et al. (1992): forward (5'-CTGGAGACCACTCCCATCCTT-3'), reverse (5'-GATGTGGCCATCACATTCGTC-3’). PCR reactions were performed in a final volume of $10 \mu \mathrm{l}$. Each PCR tube contained: $30 \mathrm{ng}$ of genomic DNA template, $0.2 \mu \mathrm{M}$ of each primer, $200 \mu \mathrm{M}$ of each dNTP, $2 \mu \mathrm{M} \mathrm{MgCl}_{2}, 1 \mu \mathrm{l}$ of $10 \times$ PCR buffer (Fermentas, Lithuania) and 0.5 U of Taq DNA polymerase (Fermentas, Lithuania). The thermocycling conditions were as follows: $95^{\circ} \mathrm{C}$ for $5 \mathrm{~min}, 30$ cycles of $95^{\circ} \mathrm{C}$ for $30 \mathrm{~s}, 63^{\circ} \mathrm{C}$ for $1 \mathrm{~min}$ and $72^{\circ} \mathrm{C}$ for $2 \mathrm{~min}$, followed by final extension at $72^{\circ} \mathrm{C}$ for $15 \mathrm{~min}$. The shorter $\mathrm{D}$ allele could be preferentially amplified and thus, to avoid mistyping of ID heterozygotes as DD homozygotes, whenever a DD genotype was found a confirmatory PCR reaction was performed, with primers specific for the insertion sequence: (forward 5'-TGGGACCACAGCGCCCGCCACTAC-3') and reverse (5'-TCGCCAGCCCTCCCATGCCCATAA-3') (Lindpaintner et al. 1995). The second PCR was performed with the same conditions except the inclusion of $10 \%$ dimethylsulfoxide (DMSO). The first PCR products were: $490 \mathrm{bp}$ (for I allele) and $202 \mathrm{bp}$ (for D allele). The second PCR products were: $337 \mathrm{bp}$ (for I allele). PCR products were separated in $2 \%$ agarose gels, stained with ethidium bromide.

The AGTR1 c. $1080 * 86 \mathrm{~A}>\mathrm{C}$ polymorphism was detected by $\mathrm{PCR} /$ restriction fragment length polymorphism (RFLP) assay. The PCR primer sequences were as follows: forward (5'-GGATGTATTGATTCAACTAGGCATC-3'), reverse (5'-AAAGTCGGTTCAGTCCACATAATGC-3’). PCR reactions were performed in a final volume of $20 \mu \mathrm{l}$ and contained $60 \mathrm{ng}$ of genomic DNA template, $0.2 \mu \mathrm{M}$ of each primer, $200 \mu \mathrm{M}$ of each dNTP, $2 \mu \mathrm{M} \mathrm{MgCl} 2,2 \mu \mathrm{l}$ of $10 \times$ PCR buffer (Fermentas, Lithuania) and $0.75 \mathrm{U}$ of Taq DNA polymerase (Fermentas, Lithuania). The thermocycling conditions were as follows: $95^{\circ} \mathrm{C}$ for $5 \mathrm{~min}, 35$ cycles of $95^{\circ} \mathrm{C}$ for $30 \mathrm{~s}, 58^{\circ} \mathrm{C}$ for $30 \mathrm{~s}$ and $72^{\circ} \mathrm{C}$ for $1 \mathrm{~min}$, followed by $72^{\circ} \mathrm{C}$ for $10 \mathrm{~min}$. The $437 \mathrm{bp}$ PCR products were digested with $4 \mathrm{U}$ of HpyF3I (DdeI isomer) restriction endonuclease (Fermentas, Lithuania) for $18 \mathrm{~h}$ at $37^{\circ} \mathrm{C}$. The resulting restriction products were: $240 \mathrm{bp}, 200 \mathrm{bp}$ for the AA genotype; $240 \mathrm{bp}, 200 \mathrm{bp}, 140 \mathrm{bp}, 60 \mathrm{bp}$ for the AC genotype and $240 \mathrm{bp}, 140 \mathrm{bp}, 60 \mathrm{bp}$ for the CC genotype. PCR and RFLP products were separated in $3 \%$ agarose gels, stained with ethidium bromide.

The CYP11B2 c.-344C $>$ T polymorphism was detected by PCR/RFLP assay. The PCR primer sequences were as follows: forward (5'-CTGTGGTGGAGGGTGTACCT-3’), reverse (5'-TCCAGGGCTGAGAGGAGTAA-3'). PCR reactions were performed in a final volume of $25 \mu \mathrm{l}$. Each PCR tube contained: $30 \mathrm{ng}$ of genomic DNA template, $0.4 \mu \mathrm{M}$ of each primer, $200 \mu \mathrm{M}$ of each dNTP, $1.5 \mu \mathrm{M}$ of $\mathrm{MgCl}_{2}, 2.5 \mu \mathrm{l}$ of $10 \times \mathrm{PCR}$ buffer (Fermentas, Lithuania) and $0.5 \mathrm{U}$ of Taq DNA polymerase (Fermentas, Lithuania). The thermocycling conditions were as follows: $95^{\circ} \mathrm{C}$ for $5 \mathrm{~min}, 35$ cycles of $95^{\circ} \mathrm{C}$ for $30 \mathrm{~s}, 59^{\circ} \mathrm{C}$ for $30 \mathrm{~s}$ and $72^{\circ} \mathrm{C}$ for $20 \mathrm{~s}$, followed by $72^{\circ} \mathrm{C}$ for $7 \mathrm{~min}$. PCR products were digested with $2 \mathrm{U}$ of $\mathrm{BsuRI}$ (HaeIII isomer) restriction enzyme (Fermentas, Lithuania) with the inclusion of bovine serum albumin (BSA) for $18 \mathrm{~h}$ at $37^{\circ} \mathrm{C}$. The resulting restriction products were: $124 \mathrm{bp}, 60 \mathrm{bp}$ for the CC genotype; $184 \mathrm{bp}, 124 \mathrm{bp}, 60 \mathrm{bp}$ for the TC genotype and $184 \mathrm{bp}$ for the TT genotype. PCR and RFLP products were separated in $3 \%$ agarose gels, stained with ethidium bromide.

\section{Statistical analyses}

The Hardy-Weinberg equilibriums for each of the genotypes tested were calculated using the chi square test. The relation of the analyzed polymorphisms and the extent of coronary atherosclerosis were compared among the groups by the Kruskal-Wallis test, followed by the Wilcoxon analyses for comparisons of two groups. $P$-values were corrected for multiple comparisons using Bonferroni method, when appropriate. The level of statistical significance was set at $P<0.05$. All statistical analyses were carried out using the SAS 9.2 package (SAS Institute Inc., Cary, NC, USA).

\section{Results}

Clinical and laboratory data of CAD patients including the atherosclerotic risk factors are summarised in Table 1. The Gensini score equals 0 for 242 patients meaning no significant 
Table 1 Clinical and laboratory data of 647 patients with $\mathrm{CAD}$

\begin{tabular}{|c|c|c|c|c|}
\hline & & \multicolumn{3}{|l|}{ Gensini score* } \\
\hline & & $\begin{array}{l}\text { All } \\
10(0-48) \\
(647)\end{array}$ & $\begin{array}{l}\text { Males } \\
26(0-61) \\
(368)\end{array}$ & $\begin{array}{l}\text { Females } \\
0(0-28) \\
(279)\end{array}$ \\
\hline \multirow[t]{6}{*}{ Smoke } & non-smoker & $0(0-31)$ & $18(0-53)$ & $0(0-16)$ \\
\hline & & $(240)$ & $(75)$ & $(165)$ \\
\hline & ex-smoker & $20(0-56)$ & $28(2-68)$ & $4(0-40)$ \\
\hline & & $(304)$ & $(220)$ & $(84)$ \\
\hline & smoker & $18.5(0-52)$ & $32(2-62)$ & $5(0-32)$ \\
\hline & & $(84)$ & $(62)$ & $(22)$ \\
\hline \multirow[t]{4}{*}{ Past MI } & No & $2(0-30)$ & $9.5(0-42)$ & $0(0-14)$ \\
\hline & & $(433)$ & $(222)$ & $(211)$ \\
\hline & Yes & $40(11-86)$ & $46(22-97)$ & $28(0-56)$ \\
\hline & & $(213)$ & $(145)$ & $(68)$ \\
\hline \multirow[t]{4}{*}{ BMI } & $\leq 25$ & $10(0-48)$ & $31(2-58)$ & $0(0-27)$ \\
\hline & & $(213)$ & $(113)$ & $(100)$ \\
\hline & $>25$ & $10(0-48)$ & $25(0-66)$ & $0(0-28)$ \\
\hline & & $(434)$ & $(255)$ & (179) \\
\hline \multirow[t]{4}{*}{ Age } & $\leq 55$ & $2(0-32)$ & $18(0-52)$ & $0(0-16)$ \\
\hline & & $(233)$ & $(87)$ & $(146)$ \\
\hline & $>55$ & $20(0-56)$ & $28(2-69)$ & $4(0-40)$ \\
\hline & & $(414)$ & $(281)$ & (133) \\
\hline \multirow[t]{4}{*}{ Diabetes mellitus } & No & $8(0-47)$ & $25(0-60)$ & $0(0-14)$ \\
\hline & & $(495)$ & $(282)$ & $(213)$ \\
\hline & Yes & $25.5(3-52.5)$ & $29(5-62)$ & $20.5(0-44)$ \\
\hline & & $(152)$ & $(86)$ & $(66)$ \\
\hline \multirow[t]{4}{*}{ Total cholesterol } & $\leq 200 \mathrm{mg} / \mathrm{dl}$ & $8(0-44)$ & $24(0-58)$ & $0(0-20)$ \\
\hline & & $(409)$ & $(249)$ & $(160)$ \\
\hline & $>200 \mathrm{mg} / \mathrm{dl}$ & $16(0-52)$ & $32(7-62)$ & $3(0-40)$ \\
\hline & & $(238)$ & $(119)$ & $(119)$ \\
\hline \multirow[t]{4}{*}{ LDL cholesterol } & $\leq 130 \mathrm{mg} / \mathrm{dl}$ & $9(0-46)$ & $27(0-64.5)$ & $0(0-20)$ \\
\hline & & $(482)$ & $(288)$ & (194) \\
\hline & $>130 \mathrm{mg} / \mathrm{dl}$ & $14(0-49)$ & $22.5(4-56)$ & $5(0-41)$ \\
\hline & & $(165)$ & $(80)$ & $(85)$ \\
\hline \multirow[t]{4}{*}{ HDL cholesterol } & $>40 \mathrm{mg} / \mathrm{dl}$ & $14(0-53)$ & $30(0-67.5)$ & $0(0-32)$ \\
\hline & & $(205)$ & (124) & $(81)$ \\
\hline & $\leq 40 \mathrm{mg} / \mathrm{dl}$ & $9(0-47)$ & $23(0-57.5)$ & $0(0-25)$ \\
\hline & & $(442)$ & $(244)$ & (198) \\
\hline \multirow[t]{4}{*}{ TG } & $\leq 150 \mathrm{mg} / \mathrm{dl}$ & $7(0-44)$ & $25(0-58)$ & $0(0-22)$ \\
\hline & & $(473)$ & $(261)$ & $(212)$ \\
\hline & $>150 \mathrm{mg} / \mathrm{dl}$ & $20(0-56)$ & $30(6-62)$ & $4(0-41)$ \\
\hline & & (174) & $(107)$ & $(67)$ \\
\hline
\end{tabular}

stenosis in their coronary arteries visualized by coronary angiography was found.

In the population as a whole, the distributions of the $A C E$ c. 2306-117 $404 \mathrm{I} / \mathrm{D}, A G T R 1$ c. $1080 * 86 \mathrm{~A}>\mathrm{C}$ and CYP11B2 c. $-34 \overline{4} \mathrm{C}>\mathrm{T}$ genotypes did not significantly differ from that expected by Hardy-Weinberg equilibrium. The distributions of Gensini scores were skewed and could not be normalized by several transformation calculations. Therefore non-parametric and ranked analyses were chosen.

We found no association between the $A C E$ c.2306$117404 \mathrm{I} / \mathrm{D}, A G T R 1$ c. $1080 * 86 \mathrm{~A}>\mathrm{C}$ and $C Y P 11 B 2$ c. $-344 \mathrm{C}>\mathrm{T}$ and the severity of coronary artery lesions in $\mathrm{CAD}$ patients in the population as a whole. 
The potential associations of examined polymorphisms and the severity of the disease were examined within groups created by subdividing the population according to: sex, smoking habit, past myocardial infarction (MI), BMI $(>25$, $\leq 25)$, age $(>55, \leq 55)$, diabetes mellitus, total cholesterol $(>200 \mathrm{mg} / \mathrm{dl}, \leq 200 \mathrm{mg} / \mathrm{dl})$, LDL cholesterol $(>130 \mathrm{mg} / \mathrm{dl}$, $\leq 130 \mathrm{mg} / \mathrm{dl}$ ), HDL cholesterol ( $>40 \mathrm{mg} / \mathrm{dl}, \leq 40 \mathrm{mg} / \mathrm{dl}$ ), TG (>150 mg/dl, $\leq 150 \mathrm{mg} / \mathrm{dl}$ ) levels.

A significant association between the $A C E$ c.2306117 404 I/D polymorphism and the extent of coronary atherosclerosis was found in men with high total cholesterol levels $(>200 \mathrm{mg} / \mathrm{dl})\left(\mathrm{P}_{\text {Kruskal-Wallis }}=0.008 ; \mathrm{P}_{\text {IIvsDallel }}=0.0023\right.$; $\left.\mathrm{P}_{\text {adjusted }}=0.009\right)$, and also in men with high LDL cholesterol levels $(>130 \mathrm{mg} / \mathrm{dl})\left(\mathrm{P}_{\text {Kruskal-Wallis }}=0.016 ; \mathrm{P}_{\text {IIvsDallel }}=0.007\right.$; $\left.\mathrm{P}_{\text {adjusted }}=0.028\right)$ and low HDL cholesterol levels $(\leq 40 \mathrm{mg} / \mathrm{dl})$ $\left(\mathrm{P}_{\text {Kruskal-Wallis }}=0.04 ; \mathrm{P}_{\text {IIvsDallel }}=0.0138 ; \mathrm{P}_{\text {adjusted }}=0.055\right)$, with the highest values of Gensini score present in the $A C E$ c.2306-117_404 D allele carriers in comparison to other genotypes (Table 2). No significant association between the $A C E$ c.2306-117_404 I/D polymorphism and the extent of coronary atherosclerosis was found when the population was analyzed in other subgroups, as listed above (data not presented).

$\mathrm{P}_{\text {Kruskal-Wallis }}=0.018$ for the association between the CYP11B2 c.-344C $>$ T polymorphism and the Gensini score was found in women with high LDL cholesterol levels (>130 mg/dl). However, after Bonferroni corrections for multiple comparisons, P-value was no longer statistically significant $\left(\mathrm{P}_{\mathrm{CCvsTallel}}=0.045 ; \mathrm{P}_{\text {adjusted }}=0.18\right)($ data not presented). No significant associations were found between the CYP11B2 c. $-344 \mathrm{C}>\mathrm{T}$ polymorphism and the Gensini score in other subgroups either (data not presented).

No significant associations between the AGTR1 c. $1080 * 86 \mathrm{~A}>\mathrm{C}$ polymorphism and the severity of coronary artery lesion in CAD patients were found in any of the subgroups analyzed (data not presented).

\section{Discussion}

The prominent role of the RAAS in the maintenance of cardiovascular homeostasis suggests that allelic variants of genes encoding for the components of this hormone system could modulate the severity of CAD. This study evaluates the association of three RAAS gene polymorphisms: $A C E$ c.2306-117_404 I/D, AGTR1 c. $1080 * 86 \mathrm{~A}>\mathrm{C}$, CYP11B2 c. $-344 \mathrm{C}>\mathrm{T}$ and the extension of coronary lesions, represented by Gensini score, which is based on the number of stenotic coronary artery segments, and a degree of the luminal narrowing and the regional importance of the
Table 2 Median Gensini score values defined by the $A C E$ c.2306-117 $404 \mathrm{I} / \mathrm{D}$ genotypes in the whole population and in subsets

\footnotetext{
*Median (N)

${ }^{\mathrm{a}} \mathrm{P}_{\mathrm{IIvsDD}}=0.0056$ for comparison of $A C E$ c.2306-117_404 II vs. $\mathrm{DD} ; \mathrm{P}_{\mathrm{IDvsDD}}=0.91$ for ID vs. DD; $\mathrm{P}_{\mathrm{IDvsII}}=0.008$ for ID vs. II, $\mathrm{P}_{\text {IIvsDallel }}=0.0023$ for II vs. $\mathrm{D}$ allel

${ }^{\mathrm{b}} \mathrm{P}_{\text {IIvsDD }}=0.007$ for comparison of $A C E$ c.2306-117_404 II vs. $\mathrm{DD} ; \mathrm{P}_{\mathrm{IDvsDD}}=0.51$ for ID vs. DD; $\mathrm{P}_{\text {IDvsII }}=0.03$ for ID vs. II, $\mathrm{P}_{\text {IIvsDallel }}=0.007$ for II vs. $\mathrm{D}$ allel ${ }^{\mathrm{c}} \mathrm{P}_{\text {IIvsDD }}=0.08$ for comparison of $A C E$ c.2306-117_404 II vs. DD; $\mathrm{P}_{\mathrm{IDvsDD}}=0.60$ for ID vs. DD; $\mathrm{P}_{\text {IDvsII }}=0.014$ for ID vs. II, $\mathrm{P}_{\text {IIvsDallel }}=0.0138$ for II vs. D allel
}

\begin{tabular}{|c|c|c|c|c|c|}
\hline & \multirow[t]{2}{*}{ Genotype: } & \multicolumn{3}{|c|}{ Gensini scale* } & \multirow[t]{2}{*}{$P_{\text {Kruskal-Wallis }}$} \\
\hline & & $\begin{array}{l}A C E \\
\mathrm{DD}\end{array}$ & $\begin{array}{l}A C E \\
\text { ID }\end{array}$ & $\begin{array}{l}A C E \\
\text { II }\end{array}$ & \\
\hline \multirow{3}{*}{$\begin{array}{l}\text { Whole investigated population } \\
\text { Sex }\end{array}$} & & $10(147)$ & $10(305)$ & $8.5(180)$ & 0.92 \\
\hline & Males & $25.5(84)$ & $31(173)$ & $23(100)$ & 0.26 \\
\hline & Females & $0(63)$ & $0(132)$ & $2.5(80)$ & 0.49 \\
\hline \multirow[t]{3}{*}{ Total cholesterol $\leq 200 \mathrm{mg} / \mathrm{dl}$} & All & $4(83)$ & $8(205)$ & $14(112)$ & 0.24 \\
\hline & Males & $9.5(50)$ & $25(122)$ & $28.5(70)$ & 0.29 \\
\hline & Females & $0(33)$ & $0(83)$ & $2.5(42)$ & 0.46 \\
\hline \multirow[t]{3}{*}{ Total cholesterol $>200 \mathrm{mg} / \mathrm{dl}$} & All & $26.5(64)$ & $17(100)$ & $4.5(68)$ & 0.09 \\
\hline & Males & $37.5(34)$ & $35(51)$ & $7(30)$ & $0.008^{\mathrm{a}}$ \\
\hline & Females & $3(30)$ & $0(49)$ & $2.5(38)$ & 0.74 \\
\hline \multirow[t]{3}{*}{ LDL cholesterol $\leq 130 \mathrm{mg} / \mathrm{dl}$} & All & $4(103)$ & $9.5(236)$ & $10.5(132)$ & 0.42 \\
\hline & Males & $16(61)$ & $32(138)$ & $28.5(80)$ & 0.32 \\
\hline & Females & $0(42)$ & $0(98)$ & $1(52)$ & 0.52 \\
\hline \multirow[t]{3}{*}{ LDL cholesterol $>130 \mathrm{mg} / \mathrm{dl}$} & All & $32(44)$ & $16(69)$ & $5.5(48)$ & 0.07 \\
\hline & Males & $37(23)$ & $25(35)$ & $7(20)$ & $0.016^{\mathrm{b}}$ \\
\hline & Females & $6(21)$ & $4(34)$ & $4.5(28)$ & 0.75 \\
\hline \multirow[t]{3}{*}{ HDL cholesterol $>40 \mathrm{mg} / \mathrm{dl}$} & All & $3(38)$ & $17.5(106)$ & $26(56)$ & 0.32 \\
\hline & Males & $26(21)$ & $30(67)$ & $38(33)$ & 0.34 \\
\hline & Females & $0(17)$ & $2(39)$ & $0(23)$ & 0.78 \\
\hline \multirow[t]{3}{*}{ HDL cholesterol $\leq 40 \mathrm{mg} / \mathrm{dl}$} & All & $11(109)$ & 9 (199) & $6(124)$ & 0.54 \\
\hline & Males & $25(63)$ & $31.5(106)$ & $10(67)$ & $0.04^{\mathrm{c}}$ \\
\hline & Females & $0(46)$ & $0(93)$ & $3(57)$ & 0.24 \\
\hline
\end{tabular}


lesion's position in the coronary tree (Gensini, 1983), and thus comprises the real reflection of the severity of the CAD.

The results we present demonstrate an association between the $A C E$ c.2306-117_404 I/D polymorphism and the extension of atherosclerosis assessed by the Gensini score, with values $\geq 0$. The association was found among men with high total cholesterol levels $(>200 \mathrm{mg} / \mathrm{dl})$, high LDL cholesterol levels ( $>130 \mathrm{mg} / \mathrm{dl})$ and low HDL cholesterol levels $(\leq 40 \mathrm{mg} / \mathrm{dl})$. Our results suggest that pro-atherosclerotic actions of angiotensin II are more pronounced when enhanced by other systemic mechanisms, such as a longlasting exposure to common CAD risk factors.

The importance of ACE in CAD etiology is undisputed. The chronic influence of higher levels of angiotensin II in the $A C E \mathrm{D}$ allele carriers, in comparison to the $\mathrm{I}$ allele carriers (Jeunemaitre 2008), may concur to the development and/or progression of atherosclerosis. The enhanced ACE expression in macrophages and smooth muscle cells of coronary artery plaques has been previously reported to indicate that $\mathrm{ACE}$ activity in lesions contributes greatly to the progression of atherosclerosis (Ohishi et al. 1997).

Our results correspond to a few previous studies. An association between the $A C E$ c.2306-117_404 D allele and the severity of CAD, described by the number of narrowings of $50 \%$ or higher and by the number of critical arterial occlusions has been reported in a Polish population (Niemiec et al. 2008a), analyzed as a whole, of 172 young (30-55 years old) subjects diagnosed with CAD. The scale chosen by Niemiec et al. (2008a) to assess the severity of CAD does not include localization of the narrowing involved in the Gensini scale but requires including at least one severe arterial narrowing. In a population of 296 patients, Mendonca et al. (2004) showed that the DD genotype is significantly linked to the severity of CAD, which has been assessed by the Leaman's score measuring the number of arteries with more than $75 \%$ stenosis and thus accounts for severe changes only. In a population of 1162 subjects Ye et al. (2003) found that among patients who carry D allele CAD has been more extensive. The severity of atherosclerosis was defined in their study as the number of coronary segments with $5-75 \%$ stenosis so patients with greater atherosclerotic extension were excluded. Also, the results of meta-analysis (Sayed-Tabatabaei et al. 2003) investigating the association between the $A C E$ c.2306-117_404 I/D polymorphism and the carotid artery intima-media thickness (IMT), used to detect the presence and to follow the progression of atherosclerosis, correspond with our work. Its authors report a positive association between the D allele and the carotid IMT, with the association being stronger among high-risk patients.

Our finding is both sex-specific and related to metabolic factor. Also, among 11 studies, which included sex interaction, described in recent meta-analysis (Zintzaras et al. 2008), six reported positive association between the $A C E$ c.2306-117 404 I/D polymorphism and CAD in males only. Zintzaras et al. (2008) suggested the actions of corticosteroid hormones affecting the activity of the RAAS might be involved. Freitas et al. (2008) demonstrated that the presence of DD genotype increases the risk of developing CAD when associated to each of classical risk factors: hypertension, obesity, diabetes and hyperlipidemia considered as total cholesterol $\geq 200 \mathrm{mg} / \mathrm{dl}, \mathrm{TG} \geq 150 \mathrm{mg} / \mathrm{dl}$, LDL cholesterol $\geq 130 \mathrm{mg} / \mathrm{dl}$ and HDL cholesterol $\leq 40 \mathrm{mg} / \mathrm{dl}$. Investigating a case-control study, Niemiec et al. (2007) concluded that the presence of the $\mathrm{D}$ allele increases the risk of CAD associated with the presence of hyperlipidemia defined by total cholesterol $\geq 5 \mathrm{mmol} / \mathrm{l}$, LDL cholesterol $\geq 3 \mathrm{mmol} / \mathrm{l}, \mathrm{TG} \geq 1,7 \mathrm{mmol} / 1$ and overweight/obesity. Hibi et al. (1997) found that the $A C E$ c.2306-117_404 I/D polymorphism correlates with the number of vessels with stenosis greater than $75 \%$, with the number of lesions with stenosis greater than $50 \%$ and extent index, calculated on the basis of percentage of the segment's length that appeared abnormal, among smokers. However, the authors did not find an association within the group with hyperlipidemia defined as total cholesterol $\geq 5.7 \mathrm{mmol} / \mathrm{l}$.

Our findings contrast with those from several studies. It is, however, important to note that the comparisons between the studies may not be accurate as various scales were applied for the measurement of atherosclerosis progression. No associations between the ACE c.2306117_404 polymorphism and the atherosclerosis extent measured by Gensini score, by the number of coronary arteries with stenosis greater than $75 \%$ (Nakauchi et al. 1996) and using other scales (Qiu et al. 2007; Foy et al. 1997; Jeunemaitre et al. 1997; van Geel et al. 2001) have been reported.

We did not find any associations between the AGTRI c. $1080 * 86 \mathrm{~A}>\mathrm{C}$ polymorphism and the severity of CAD as determined by Gensini score either within the whole population or in any of the investigated subgroups. Such a result is supported by a recent meta-analysis (Xu et al. 2010) which includes 53 studies. The authors conclude that there is only a weak association between the AGTR1 c. $1080 * 86 \mathrm{~A}>\mathrm{C}$ polymorphism and coronary heart disease. Similarly, no association between the AGTR1 c. $1080 * 86 \mathrm{~A}>\mathrm{C}$ polymorphism and the Gensini score (Gardemann et al. 1998; Nakauchi et al. 1996), number of arteries stenosed (Gardemann et al. 1998; van Geel et al. 2001) and the angiographic score (Jeunemaitre et al. 1997) has been found. Interestingly, Nakauchi et al. (1996) report that among the patients with the AC genotype the number of arteries narrowed by $75 \%$ was higher than among those carrying the AA genotype. Further, Qiu et al. (2007) found that the AGTR1 c. $1080 * 86 \mathrm{~A}>\mathrm{C}$ polymorphism may be involved in the 
severity of CAD, with the number of stenosed vessels and the coronary jeopardy score greater in the patients with the $\mathrm{AC}$ genotype than in those with the AA genotype.

Our results are in agreement with those reported by Freitas et al. (2008), who did not find any association between the AGTR1 c. $1080 * 86 \mathrm{~A}>\mathrm{C}$ polymorphism and the increased risk of CAD, also in the context of dislipidemia, defined as total cholesterol $\geq 200 \mathrm{mg} / \mathrm{dl}$, TG $\geq 150 \mathrm{mg} / \mathrm{dl}$, LDL cholesterol $\geq 130 \mathrm{mg} / \mathrm{dl}$ and HDL cholesterol $\geq 40 \mathrm{mg} / \mathrm{dl}$. However, Niemiec et al. (2008b) found that the $\mathrm{C}$ allele is associated with a higher risk of CAD in patients with hypercholesterolemia (total cholesterol level $\geq 5 \mathrm{mmol} / \mathrm{l}$ ).

The association between the CYP11B2 c.-344C $>\mathrm{T}$ polymorphism and the extent of coronary atherosclerosis has not been investigated before in patients who had undergone first-time coronary angiography. In our study, this polymorphism has not been associated with the extent of coronary atherosclerosis directly or via interactions with commonly known atherosclerotic risk factors. Interestingly, the CYP11B2 c. $-344 \mathrm{C}>\mathrm{T}$ polymorphism has been associated with the progression of atherosclerotic plaque size in the carotid artery (Sharma and Katz 2010). Our results are in agreement with previous investigations reporting no association between the CYP11B2 c.-344C $>\mathrm{T}$ polymorphism and bypass degradation measured by adjusted Gensini score (Ortlepp et al. 2001), stent restenosis (Ryu et al. 2002), caroid IMT (Balkestein et al. 2002; Sarzani et al. 2003) and overall CAD events risk in 2490 healthy men (Payne et al. 2004). Therefore, further studies regarding the association between the CYP11B2 c. $-344 \mathrm{C}>\mathrm{T}$ polymorphism and atherosclerosis progression would be of interest.

\section{Conclusions}

In this study, we investigated the association between the $A C E$ c.2306-117_404 I/D, AGTR1 c. $1080 * 86 \mathrm{~A}>\mathrm{C}$ and CYP11B2 c. $-344 \mathrm{C}>\mathrm{T}$ polymorphisms, within the genes encoding for RAAS proteins, and the extent of atherosclerosis. The association was searched in groups of patients, selected according to common CAD risk factors, such as abnormal lipids profile. Our results suggest that those men who carry the $A C E$ c.2306-117_404 DD genotype and who have high total, high LDL or low HDL cholesterol levels may be more predisposed to the development of more severe CAD. No association between the AGTR1 c. $1080 * 86 \mathrm{~A}>\mathrm{C}$ or CYP11B2 c. $-344 \mathrm{C}>\mathrm{T}$ polymorphisms and the extent of atherosclerosis in $\mathrm{CAD}$ has been found.

Acknowledgements The work was supported by the Polish State Committee for Scientific Research grant No. 2P05B 127 27. The authors declare no conflict of interest.
Open Access This article is distributed under the terms of the Creative Commons Attribution License which permits any use, distribution, and reproduction in any medium, provided the original author(s) and the source are credited.

\section{References}

Agerholm-Larsen B, Nordestgaard BG, Tybjaerg-Hansen A (2000) ACE gene polymorphism in cardiovascular disease: metaanalyses of small and large studies in whites. Arterioscler Thromb Vasc Biol 20:484-492

Balkestein EJ, Wang JG, Struijker-Boudier HA, Barlassina C, Bianchi G, Birkenhager WH, Brand E, Den Hond E, Fagard R, Herrmann SM, Van Bortel LM, Staessen JA (2002) Carotid and femoral intima-media thickness in relation to three candidate genes in a Caucasian population. J Hypertens 20:1551-1561

Casiglia E, Tikhonoff V, Mazza A, Rynkiewicz A, Limon J, Caffi S, Guglielmi F, Martini B, Basso G, Winnicki M, Pessina AC, Somers VK (2005) C-344T polymorphism of the aldosterone synthase gene and blood pressure in the elderly: a populationbased study. J Hypertens 23:1991-1996

Ceolotto G, Papparella I, Bortoluzzi A, Strapazzon G, Ragazzo F, Bratti P, Fabricio AS, Squarcina E, Gion M, Palatini P, Semplicini A (2011) Interplay between miR-155, AT1R A1166C polymorphism, and AT1R expression in young untreated hypertensives. Am J Hypertens 24:241-246

Farmer JA, Torre-Amione G (2001) The renin angiotensin system as a risk factor for coronary artery disease. Curr Atheroscler Rep 3:117-124

Foy CA, Rice GI, Ossei-Gerning N, Mansfield MW, Grant PJ (1997) Angiotensin-converting enzyme (ACE) gene polymorphisms in patients characterised by coronary angiography. Hum Genet 100:420-425

Freitas AI, Mendonca I, Brion M, Sequeira MM, Reis RP, Carracedo A, Brehm A (2008) RAS gene polymorphisms, classical risk factors and the advent of coronary artery disease in the Portuguese population. BMC Cardiovasc Disord 8:15

Gardemann A, Nguyen QD, Humme J, Stricker J, Katz N, Tillmanns H, Hehrlein FW, Rau M, Haberbosch W (1998) Angiotensin II type 1 receptor A1166C gene polymorphism. Absence of an association with the risk of coronary artery disease and myocardial infarction and of a synergistic effect with angiotensinconverting enzyme gene polymorphism on the risk of these diseases. Eur Heart J 19:1657-1665

Gensini GG (1983) A more meaningful scoring system for determining the severity of coronary heart disease. Am J Cardiol 51:606

Hibi K, Ishigami T, Kimura K, Nakao M, Iwamoto T, Tamura K, Nemoto T, Shimizu T, Mochida Y, Ochiai H, Umemura S, Ishii M (1997) Angiotensin-converting enzyme gene polymorphism adds risk for the severity of coronary atherosclerosis in smokers. Hypertension 30:574-579

Jeunemaitre X (2008) Genetics of the human renin angiotensin system. J Mol Med (Berl) 86:637-641

Jeunemaitre X, Ledru F, Battaglia S, Guillanneuf MT, Courbon D, Dumont C, Darmon O, Guize L, Guermonprez JL, Diebold B, Ducimetiere P (1997) Genetic polymorphisms of the reninangiotensin system and angiographic extent and severity of coronary artery disease: the CORGENE study. Hum Genet 99:6673

Lindpaintner K, Pfeffer MA, Kreutz R, Stampfer MJ, Grodstein F, LaMotte F, Buring J, Hennekens CH (1995) A prospective evaluation of an angiotensin-converting-enzyme gene polymorphism and the risk of ischemic heart disease. N Engl J Med 332:706-711 
Martin MM, Buckenberger JA, Jiang J, Malana GE, Nuovo GJ, Chotani M, Feldman DS, Schmittgen TD, Elton TS (2007) The human angiotensin II type 1 receptor $+1166 \mathrm{~A} / \mathrm{C}$ polymorphism attenuates microrna-155 binding. J Biol Chem 282:24262-24269

Mendonca I, Freitas IA, Sousa CA, Gomes S, Faria P, Drumond A, Silva G, Araujo JJ, Freitas S, Ornelas I, Andrade G, Coelho AP, Silva PM, Cardoso A, Brehm AA, dos Reis RP (2004) Polymorphism of the ACE gene is associated with extent and severity of coronary disease. Rev Port Cardiol 23:1605-1611

Nakauchi Y, Suehiro T, Yamamoto M, Yasuoka N, Arii K, Kumon Y, Hamashige N, Hashimoto K (1996) Significance of angiotensin Iconverting enzyme and angiotensin II type 1 receptor gene polymorphisms as risk factors for coronary heart disease. Atherosclerosis 125:161-169

Niemiec P, Zak I, Wita K (2007) Modification of the coronary artery disease risk associated with the presence of traditional risk factors by insertion/deletion polymorphism of the ACE gene. Genet Test 11:353-359

Niemiec P, Zak I, Wita K (2008a) The D allele of angiotensin Iconverting enzyme gene insertion/deletion polymorphism is associated with the severity of atherosclerosis. Clin Chem Lab Med $46: 446-452$

Niemiec P, Zak I, Wita K (2008b) The risk of coronary artery disease associated with cigarette smoking and hypercholesterolemia is additionally increased by the presence of the AT1R gene 1166C allele. Biochem Genet 46:799-809

Ohishi M, Ueda M, Rakugi H, Naruko T, Kojima A, Okamura A, Higaki J, Ogihara T (1997) Enhanced expression of angiotensinconverting enzyme is associated with progression of coronary atherosclerosis in humans. J Hypertens 15:1295-1302

Ortlepp JR, Janssens U, Bleckmann F, Lauscher J, Merkelbach-Bruse S, Hanrath P, Hoffmann R (2001) A chymase gene variant is associated with atherosclerosis in venous coronary artery bypass grafts. Coron Artery Dis 12:493-497

Payne JR, Dhamrait SS, Toor IS, Cooper J, Jones A, Miller GJ, Humphries SE, Montgomery HE (2004) The $-344 \mathrm{~T}>\mathrm{C}$ promoter variant of the gene for aldosterone synthase (CYP11B2) is not associated with cardiovascular risk in a prospective study of UK healthy men. Atherosclerosis 174:81-86

Qiu C, Han Z, Lu W (2007) Association of polymorphisms in angiotensin-converting enzyme and type 1 angiotensin II receptor genes with coronary heart disease and the severity of coronary artery stenosis. J Huazhong Univ Sci Technolog Med Sci 27:660-663

Rigat B, Hubert C, Alhenc-Gelas F, Cambien F, Corvol P, Soubrier F (1990) An insertion/deletion polymorphism in the angiotensin Iconverting enzyme gene accounting for half the variance of serum enzyme levels. J Clin Invest 86:1343-1346
Rigat B, Hubert C, Corvol P, Soubrier F (1992) PCR detection of the insertion/deletion polymorphism of the human angiotensin converting enzyme gene (DCP1) (dipeptidyl carboxypeptidase 1). Nucleic Acids Res 20:1433

Ryu SK, Cho EY, Park HY, Im EK, Jang YS, Shin GJ, Shim WH, Cho SY (2002) Renin-angiotensin-aldosterone system (RAAS) gene polymorphism as a risk factor of coronary in-stent restenosis. Yonsei Med J 43:461-472

Sarzani R, Salvi F, Dessi-Fulgheri P, Catalini R, Mazzara D, Cola G, Siragusa N, Spagnolo D, Ercolani P, Gesuita R, Carle F, Rappelli A (2003) Aldosterone synthase alleles and cardiovascular phenotype in young adults. J Hum Hypertens 17:859-864

Sayed-Tabatabaei FA, Houwing-Duistermaat JJ, van Duijn CM, Witteman JC (2003) Angiotensin-converting enzyme gene polymorphism and carotid artery wall thickness: a meta-analysis. Stroke 34:1634-1639

Sharma R, Katz J (2010) Preliminary studies on human aldosterone synthase (CYP11B2) gene polymorphism, matrix metalloprotease9, apoptosis, and carotid atherosclerosis plaque size by proton magnetic resonance imaging. J Renin Angiotensin Aldosterone Syst 11:198-204

Sookoian S, Gianotti TF, Gonzalez CD, Pirola CJ (2007) Association of the C-344T aldosterone synthase gene variant with essential hypertension: a meta-analysis. J Hypertens 25:5-13

Tsukada K, Ishimitsu T, Teranishi M, Saitoh M, Yoshii M, Inada H, Ohta S, Akashi M, Minami J, Ono H, Ohrui M, Matsuoka H (2002) Positive association of CYP11B2 gene polymorphism with genetic predisposition to essential hypertension. J Hum Hypertens 16:789-793

van Geel PP, Pinto YM, Zwinderman AH, Henning RH, van Boven AJ, Jukema JW, Bruschke AV, Kastelein JJ, van Gilst WH (2001) Increased risk for ischaemic events is related to combined RAS polymorphism. Heart 85:458-462

White PC, Rainey WE (2005) Editorial: polymorphisms in CYP11B genes and 11-hydroxylase activity. J Clin Endocrinol Metab 90:1252-1255

Xu M, Sham P, Ye Z, Lindpaintner K, He L (2010) A1166C genetic variation of the angiotensin II type I receptor gene and susceptibility to coronary heart disease: collaborative of 53 studies with 20,435 cases and 23,674 controls. Atherosclerosis 213:191-199

Ye S, Dhillon S, Seear R, Dunleavey L, Day LB, Bannister W, Day IN, Simpson I (2003) Epistatic interaction between variations in the angiotensin I converting enzyme and angiotensin II type 1 receptor genes in relation to extent of coronary atherosclerosis. Heart 89:1195-1199

Zintzaras E, Raman G, Kitsios G, Lau J (2008) Angiotensin-converting enzyme insertion/deletion gene polymorphic variant as a marker of coronary artery disease: a meta-analysis. Arch Intern Med 168:1077-1089 